Article

\title{
Evaluation of Alkaloids Isolated from Ruta graveolens as Photosynthesis Inhibitors
}

\author{
Olívia Moreira Sampaio ${ }^{1}$, Lucas Campos Curcino Vieira ${ }^{2}{ }^{-0}$, Barbara Sayuri Bellete ${ }^{3}$, \\ Beatriz King-Diaz ${ }^{4}$, Blas Lotina-Hennsen ${ }^{4}$, Maria Fátima das Graças Fernandes da Silva ${ }^{5}$ (D) \\ and Thiago André Moura Veiga ${ }^{6, *}$ (D) \\ 1 Department of Chemistry, Federal University of Mato Grosso, \\ Cuiabá-MT 78068-600, Brazil; olysampa@ufmt.br \\ 2 Engineering Institute, Federal University of Mato Grosso, \\ Várzea Grande-MT 78060-900, Brazil; lucasccurcino@gmail.com \\ 3 Department of Chemistry, Federal University of Lavras, \\ Minas Gerais-MG 37200-000, Brazil; barbarabellete@gmail.com \\ 4 Department of Biochemistry, University Nacional Autonoma de Mexico, \\ Mexico City 04510, Mexico; kingbeat@unam.mx (B.K.-D.); blas@unam.mx (B.L.-H.) \\ 5 Department of Chemistry, Federal University of São Carlos, São Carlos-SP 13565-905, Brazil; dmfs@ufscar.br \\ 6 Department of Chemistry, Federal University of São Paulo, Diadema-SP 09972-270, Brazil \\ * Correspondence: tveiga@unifesp.br; Tel.: +55-11-4044-0500
}

Academic Editor: John C. D'Auria

Received: 12 September 2018; Accepted: 6 October 2018; Published: 19 October 2018

\begin{abstract}
Eight alkaloids (1-8) were isolated from Ruta graveolens, and their herbicide activities were evaluated through in vitro, semivivo, and in vivo assays. The most relevant results were observed for Compounds 5 and 6-8 at $150 \mu \mathrm{M}$, which decreased dry biomass by $20 \%$ and $23 \%$, respectively. These are significant results since they presented similar values with the positive control, commercial herbicide 3-(3,4-dichlorophenyl)-1,1-dimethylurea (DCMU). Based on the performed assays, Compound 5 (graveoline) is classified as an electron-transport inhibitor during the light phase of photosynthesis, as well as a plant-growth regulator. On the other hand, Compounds 6-8 inhibited electron and energy transfers, and are also plant-growth inhibitors. These phytotoxic behaviors based on acridone and quinolone alkaloids may serve as a valuable tool in the further development of a new class of herbicides since natural products represent an interesting alternative to replace commercial herbicides, potentially due their low toxicity.
\end{abstract}

Keywords: Ruta graveolens; photosystem II; Chl a fluorescence; Hill reaction inhibitors; acridone alkaloids

\section{Introduction}

Ruta graveolens L. (Rutaceae) is a medicinal plant whose roots and aerial parts contain more than 120 special metabolites as coumarins, flavonoids, acridones, and furoquinoline alkaloids [1,2]. Many of these metabolites have attracted biological and pharmacological interest, demonstrating antifungal, phytotoxic, and antidotal activities [3-9]. In this context, the effect of the natural products as photosynthesis inhibitors has been efficiently evaluated [10-12]. The photosynthetic process is divided into three parts: the initial light-harvesting process and local charge separation, proton-coupled electron transfer, and multielectronic redox catalysis [13]. During the phenomenon, light absorption by antenna molecules is followed by efficient charge separation across the membrane via photosynthetic reaction centers [14]. The antenna system absorbs and converts light into chemical energy at $P_{680}$. Accordingly, charge recombination is prevented by the presence of an electron-transport chain driving electrons towards $\mathrm{P}_{700}$; a second light-harvesting process occurs at photosystem I (PSI), 
providing additional energy to electrons for their final purpose: production of adenosine triphosphate (ATP) and dihydronicotinamide-adenine dinucleotide phosphate (NADPH), which are used for $\mathrm{CO}_{2}$ fixation through the Calvin cycle (biochemistry phase) $[13,14]$. Therefore, we analyzed chlorophyll $a$ fluorescence kinetic transients to verify the damage on photosynthetic apparatus, demonstrating the quantitative and qualitative effects of herbicides on both photosystems [15,16]. From this perspective, the main goal of this report was to investigate the effects of alkaloids (1-8) isolated from Ruta graveolens L. (Figure 1) on photosynthetic activities through polarography, chlorophyll (Chl) $a$ fluorescence, and in vivo plant-growth experiments. Our results suggested that these techniques are powerful and sensitive enough to localize, in detail, the mechanisms of action related to such a complex target, photosynthesis.<smiles>[R]c1c([R])c([R])c2c(c1[R])c(=O)c1ccccc1n2C</smiles>

$1 \mathrm{R}_{1}: \mathrm{OH} ; \mathrm{R}_{2}: \mathrm{OMe} ; \mathrm{R}_{3}: \mathrm{OMe} ; \mathrm{R}_{4}: \mathrm{H}$ $2 \mathrm{R}_{1}: \mathrm{OH} ; \mathrm{R}_{2}: \mathrm{OMe} ; \mathrm{R}_{3}: \mathrm{OMe} ; \mathrm{R}_{4}: \mathrm{OH}$ $3 \mathrm{R}_{1}: \mathrm{OH} ; \mathrm{R}_{2}: \mathrm{H} ; \mathrm{R}_{3}: \mathrm{OMe} ; \mathrm{R}_{4}: \mathrm{H}$

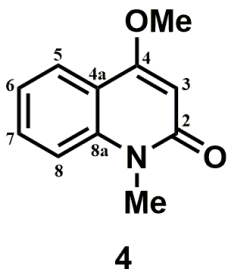

Figure 1. Alkaloids isolated from Ruta graveolens.

\section{Results and Discussion}

\subsection{Effect of Alkaloids 1-8 on Noncyclic Electron Transport and $H^{+}$-ATPase Activity}

Compounds 2 and 3 did not present an effect on noncyclic electron transport in preliminary tests. On the other hand, the other alkaloids inhibited noncyclic electron transport from $\mathrm{H}_{2} \mathrm{O}$ to methylviologen (MV) in chloroplasts isolated from Spinacea oleracea L. Arborinine (1) inhibited phosphorylating and uncoupled electron flow by $100 \%$ at $100 \mu \mathrm{M}$, which demonstrated that (1) behaves as a potent electron-transport inhibitor (Figure 2A). The basal electron flow was increased at low concentrations (around $15 \mu \mathrm{M}$ ), but electron flow at concentrations higher than $25 \mu \mathrm{M}$ was decreased, inhibiting electron flow by $20 \%$ at $100 \mu \mathrm{M}$, which means that (1) binds to the $\mathrm{CF}_{1} \mathrm{CF}_{0}$-ATPase complex, suggesting inhibitory activity on ATP synthesis. The results found, with regard to electron-transport reaction, a increment of the step as well as a decrease in the phosphorylating and uncoupled steps, indicating that (1) exhibited a dual effect by inhibiting both energy transfer and electron transport [17].

Compound 4 increased basal and phosphorylating electron transports by $80 \%$ and $40 \%$, respectively, at the beginning of the illumination, and then decreased them, since the concentrations were higher than $80 \mu \mathrm{M}$ (Figure 2B). As well as Compound (1), (4) decreased the uncoupled phase at concentrations close to $80 \mu \mathrm{M}$. Therefore, (4) did not demonstrate electron-transport inhibition, but rather acted as a decoupling agent. Graveoline (5) inhibited the basal, phosphorylating, and uncoupled electron transport by $40 \%$ at $300 \mu \mathrm{M}$, which suggested Hill reaction inhibitory behavior (Figure 2C).

Homolog mixture 6-8 inhibited energy transfer at $25 \mu \mathrm{M}$ and showed slight inhibitory activity on electron-transport reactions at concentrations up to $100 \mu \mathrm{M}$ (Figure 2D). Compounds 6-8 increased basal and phosphorylating electron transport by $230 \%$ and $140 \%$, respectively. The uncoupled electron transport showed a small increase in concentrations below $100 \mu \mathrm{M}$. In this way, the mixture behaved mainly as an energy-transfer inhibitor and showed electron-transport inhibitory activity at higher concentrations. 

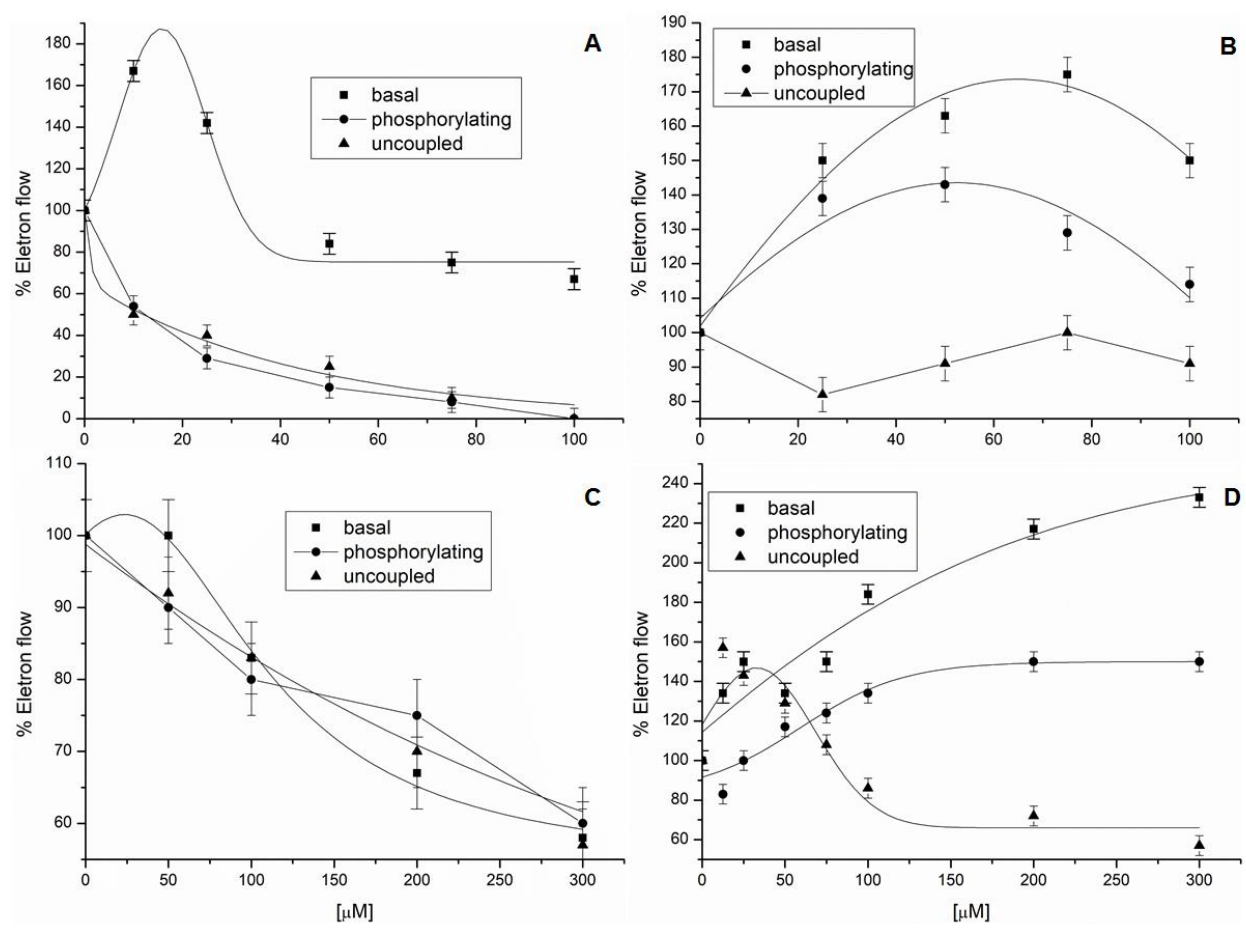

Figure 2. Effect of the alkaloids isolated from R. graveolens on electron flow. Control-rate values for electron transport from basal, phosphorylating, and uncoupled conditions were 450, 620, and 1200 uequiv $\mathrm{e}^{-} \mathrm{h}^{-1} \mathrm{mg}^{-1}$ chlorophyll $(\mathrm{Chl})^{-1}$, respectively. Panel (A): Compound 1; Panel (B): Compound 4; Panel (C): Compound 5; and Panel (D): Mixtures 6-8.

When there is a significant increase on the basal electron-transport step, as observed for Compounds 1, 4, and 6-8, this is an indication that the compounds are acting on the ATP-synthase complex [17]. Cyclic electron transport is happening normally, as can be observed in the basal reaction, due the behavior of the chloroplasts in the reaction medium. The percentage of the basal curve means that the effect is happening over the ATP-synthase complex once the basal reaction works harder to equilibrate this damage, thus increasing the speed of action.

Due to this, ATPase analysis for Compounds 1, 4, and 6-8 was needed to confirm if they interfere on the $\mathrm{CF}_{1} \mathrm{CF}_{0}$-ATPase complex, acting by direct inhibition of ATP synthesis. The experiments (Table 1) revealed that Compound 4 binds to $\mathrm{CF}_{1} \mathrm{CF}_{0}$-ATPase complex exerting a direct inhibition of the $\mathrm{H}^{+}$ gradient dissipation and the Compounds $\mathbf{1}$ and $\mathbf{6 - 8}$ act as energy transfer inhibitors $\left(\mathrm{H}^{+}\right.$-ATPase inhibitor) [17].

The electron-transport increase on the basal reaction up to $100 \%$ indicates that the compounds acted on the ATP-synthase complex, blocking the energy transfer or acting as proton-transfer decoupling. This behavior was observed for Compounds $\mathbf{1}$ and 6-8 through the increase of the basal step for Compound 4 by the increment of the basal and phosphorylating reactions $[18,19]$.

To confirm if Compounds $\mathbf{1}$ and $\mathbf{6 - 8}$ act as energy-transfer inhibitors, and if Compound $\mathbf{4}$ acts as a decoupling agent, we performed $\mathrm{H}^{+}$-ATPase assays to verify their effect on the catalytic unit of the $\mathrm{H}^{+}$-ATPase complex $\left(\mathrm{CF}_{0}-\mathrm{CF}_{1}\right)$ [17]. Compounds $\mathbf{1}$ and 6-8 inhibited the energy transfer, as they decreased the inorganic phosphate (Pi) concentrations in the reaction medium by $25 \%$ at $100 \mu \mathrm{M}$ and $300 \mu \mathrm{M}$, respectively. Corroborating the electron-transport data, both compounds are inhibitors of the $\mathrm{CF}_{0}-\mathrm{CF}_{1}$ enzymatic site of the ATPase complex (Table 1). In its turn, Compound 4 increased Pi concentration by $18 \%$ at $100 \mu \mathrm{M}$, which confirmed its proton-gradient uncoupling profile. 
Table 1. Effect of Compounds 1, 4, and 6-8 on inorganic phospate (Pi).

\begin{tabular}{ccc}
\hline Compound & $(\boldsymbol{\mu M})$ & $\boldsymbol{P} \boldsymbol{i}(\mathbf{\%})$ \\
\hline Control & $\mathbf{0}$ & $\mathbf{1 0 0}$ \\
\hline \multirow{3}{*}{$\mathbf{1}$} & 25 & 90 \\
& 50 & 78 \\
& 100 & 77 \\
\hline \multirow{4}{*}{4} & 25 & 104 \\
& 50 & 108 \\
& 100 & 118 \\
\hline \multirow{2}{*}{$\mathbf{6 - 8}$} & 100 & 93 \\
& 200 & 88 \\
& 300 & 77 \\
\hline
\end{tabular}

\subsection{Uncoupled PSI and PSII Electron-Flow Determination}

To localize the inhibition sites of the alkaloids on the thylakoid electron-transport chain, their effects on PSI and PSII (including partial reactions) were evaluated employing artificial donors and acceptors of electrons, as well as appropriate inhibitors [20]. Arborinine (1) inhibited uncoupled electron transport on PSII from water to DCBQ (from $\mathrm{H}_{2} \mathrm{O}$ to $\mathrm{Q}_{B}$ ) and the partial reactions from water to sodium silicomolybdate ( $\mathrm{SiMo}$ ) (from $\mathrm{H}_{2} \mathrm{O}$ to $\mathrm{Q}_{\mathrm{A}}$ ) by $60 \%$ at $400 \mu \mathrm{M}$ (Table 2). There were no significant results $(<4 \%)$ for the reactions from DPC to 2,6-dichlorophenolindophenol (DCPIP) (from $\mathrm{P}_{680}$ to $\left.\mathrm{Q}_{\mathrm{B}}\right)$.

Table 2. Effects of arborinine (1) on photosynthetic electron transport on photosystem II (PSII). Note: DCPIP, 2,6-dichlorophenolindophenol.

\begin{tabular}{|c|c|c|c|c|c|c|}
\hline \multirow[t]{2}{*}{$(\mu \mathrm{M})$} & \multicolumn{2}{|c|}{$\mathrm{H}_{2} \mathrm{O}$ to DCBQ } & \multicolumn{2}{|c|}{$\mathrm{H}_{2} \mathrm{O}$ to Sodium Silicomolybdate (SiMo) } & \multicolumn{2}{|c|}{ DPC to DCPIP } \\
\hline & $a$ & $b$ & $A$ & $b$ & $C$ & $b$ \\
\hline 0 & $547.5 \pm 2.74$ & 100 & $511.0 \pm 2.56$ & 100 & $256.0 \pm 1.28$ & 100 \\
\hline 50 & - & - & - & - & $283.0 \pm 1.42$ & 110.6 \\
\hline 100 & $401.5 \pm 2.00$ & 74 & $328.5 \pm 1.64$ & 65 & $268.0 \pm 1.34$ & 104.5 \\
\hline 200 & $292.0 \pm 1.46$ & 54 & $255.5 \pm 1.28$ & 50 & $268.0 \pm 1.34$ & 104.5 \\
\hline 300 & $255.5 \pm 1.28$ & 47 & $237.3 \pm 1.19$ & 47 & - & - \\
\hline 400 & $219.0 \pm 1.09$ & 40 & $219.0 \pm 1.09$ & 43 & - & - \\
\hline
\end{tabular}

The polarographic measures indicated that 1 inhibited the passage from $\mathrm{H}_{2} \mathrm{O}$ to $\mathrm{Q}_{A}$, that is, on both sides of the electron transport on PSII. The first inhibition site $\left(\mathrm{H}_{2} \mathrm{O}\right.$ to SiMo) occurs in the enzyme where water photo-oxidation happens, and the other at DPC (donates electron at P680) to DCPIPox (accepts electrons at $Q_{B}$ site), located at the water-splitting enzyme complex (OEC) and between the range of electron flow from P680 to $Q_{A}$. These results indicated that 1 inhibited PSII at the span of electron transport from $\mathrm{H}_{2} \mathrm{O}$ to $\mathrm{Q}_{\mathrm{A}}$ due the fact that SiMo accepts electrons exactly at the $\mathrm{Q}_{\mathrm{A}}$ site. Table 2 shows that the span of electron transport from $\mathrm{P} 680$ to $\mathrm{Q}_{\mathrm{B}}$ was not inhibited in all concentrations. Compound 1 inhibited the PSI uncoupled electron transport from reduced DCPIP to $\mathrm{MV}$ by $50 \%$ at $200 \mu \mathrm{M}$ (Table 3). However, no changes were observed on inhibitory activity at higher concentrations. 
Table 3. Effects of arborinine (1) on photosynthetic uncoupled electron transport at PSI.

\begin{tabular}{|c|c|c|}
\hline \multirow[t]{2}{*}{$(\mu \mathrm{M})$} & \multicolumn{2}{|c|}{ DCPIP $_{\text {red }}$ a Methylviologen (MV) } \\
\hline & $a$ & $b$ \\
\hline 0 & $1467.4 \pm 7.34$ & 100 \\
\hline 100 & $867.1 \pm 4.34$ & 59.1 \\
\hline 200 & $733.7 \pm 3.67$ & 50 \\
\hline 400 & $667.0 \pm 3.34$ & 46 \\
\hline
\end{tabular}

\subsection{Chl a Fluorescence Measurements in Spinach Leaf Discs}

The Chl $a$ fluorescence assay is a widely used tool to evaluate the photosynthetic apparatus in plants submitted to different stresses, as well as to provide detailed information about the structure and function of PSII $[10,20]$. For this experiment, all alkaloids were evaluated at 150 and $300 \mu \mathrm{M}$. Compounds 1-4 showed very low activity during the experiment, less than $20 \%$ compared to negative control (data not shown).

Compound 5 increased $\mathrm{dV} / \mathrm{dt}_{0}$ and decreased $\mathrm{PI}_{a b s}$, both parameters by $60 \%$ at $150 \mu \mathrm{M}$, which represents a stressful event occurring in the plant. The association of these parameters suggests that the natural redox process of photosynthesis was interfered with (Figure $3 \mathrm{~A}$ ). Parameters $\mathrm{PSI}_{0}$, $\mathrm{PHI}\left(\mathrm{E}_{0}\right), \mathrm{S} m, \mathrm{ET}_{0} / \mathrm{CS}_{0}$, and $\mathrm{ET}_{0} / \mathrm{RC}$ were reduced by $40 \%$, which directly represents that electron transport on the redox process was interrupted, indicating damage to PSII. The decrease in Sm demonstrates that not all absorbed energy was used, and then it was eliminated from the process. Energy dissipation was confirmed through the increase of the nonphotochemical "de-excitation" constant $(\mathrm{K} n)$ by $40 \%$ and the quantum yield $(\mathrm{t}=0$ ) of dissipation energy (PHI $(\mathrm{Do})$ ) by $20 \%$. Thus, the energy contained in the system was released as heat or transferred to another molecule.

Compounds 6-8 were active at both concentrations during the leaf-disc fluorescence assay (Figure 3A,B). The $\mathrm{PI}_{a b s}$ parameter showed a decrease of $70 \%$ at $150 \mu \mathrm{M}$, indicating a nontraditional photosynthesis process. Parameters $\mathrm{PSI}_{0}, \mathrm{PHI}\left(\mathrm{E}_{0}\right), \mathrm{ET}_{0} / \mathrm{CS}_{0}$ and $\mathrm{ET}_{0} / \mathrm{RC}$ were reduced by 40,40 , 60 and $40 \%$, respectively, at $150 \mu \mathrm{M}$. These decrements represent damage in electron transport on PSII, showing that the calculated quantum-yield values for the electron transport decreased in the process of the flux being inhibited. The reduction of $\mathrm{ET}_{0} / \mathrm{CS}_{0}, \mathrm{ET}_{0} / \mathrm{RC}$, and $\mathrm{RC} / \mathrm{CS}_{0}$ parameters by $30 \%$ indicated that the electron transport was being blocked, as well as a reduction in reaction centers participating in the process. Like Compound 5, the increment was promoted by the mixture of analogs on the $\mathrm{dV} / \mathrm{dt}_{0}, \mathrm{SmK}, \mathrm{K} n$, and $\mathrm{PHI}\left(\mathrm{D}_{0}\right)$ parameters.
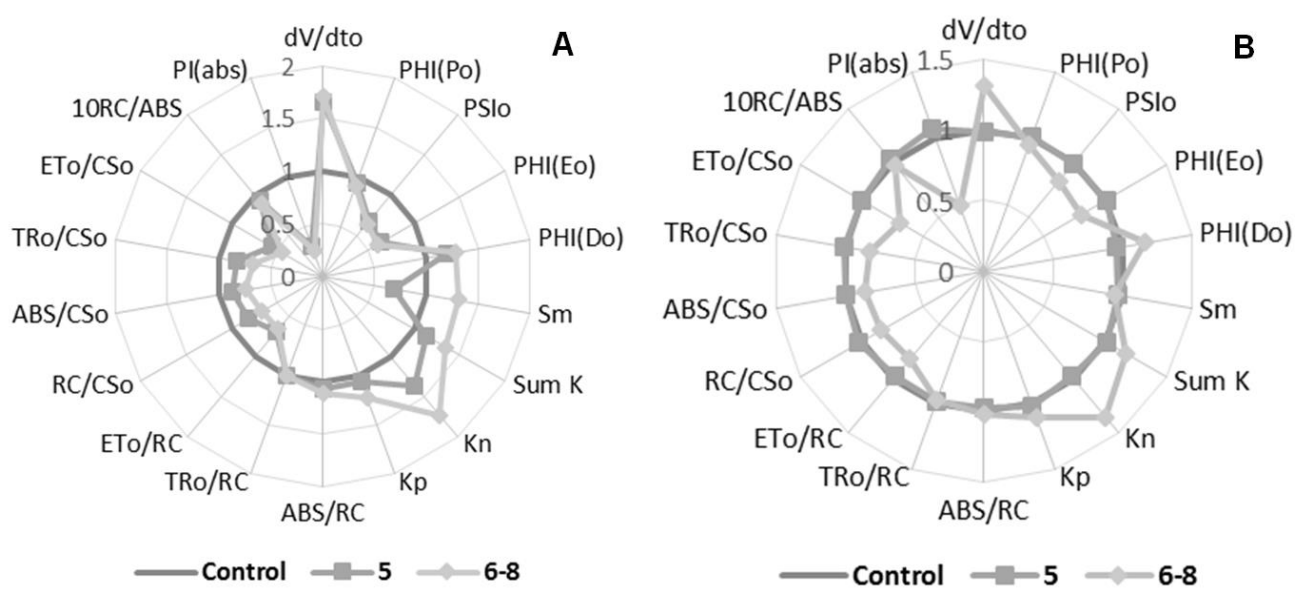

Figure 3. Radar plot of Compounds 5 and 6-8 effects on Chl $a$ fluorescence parameters calculated from an OJIP transient curve. Panel (A) $150 \mu \mathrm{M}$, and Panel (B) $300 \mu \mathrm{M}$. 
A $J$ band (2 ms) was observed at the OJIP transient curve for Compound $5(150 \mu \mathrm{M})$, which indicates inhibition at the quinone level, on the acceptor side of PSII (Figure 4A). An increase at $J$ step can be understood as evidence for reduced-form QA accumulation ( $\mathrm{QA}^{-}$) due electron-transport deceleration beyond QA [21]. Since the PSII electron flux was inhibited, the maximum PSII microelectrons field carries less $\mathrm{QA}^{-}$. This aspect corroborated the reduction of the $\mathrm{PSI}_{0}$ and $\mathrm{PHI}\left(\mathrm{E}_{0}\right)$ quantum parameters. The results of the fluorescence emission on spinach-leaf discs confirm the in vitro electron transport results, which revealed Compound 5 acting as a Hill reaction inhibitor.

The same $J$ band was observed when the mixture of quinolone alkaloids was submitted to the assays (Figure 4B), which confirms that Compounds 6-8 also behave like 3-(3,4-dichlorophenyl)1,1-dimethylurea (DCMU), inhibiting the acceptor side of the PSII [10]. The Chl $a$ experiment also showed the appearance of the $I$ band near $30 \mathrm{~ms}$ (Figure 4C), which exclusively refers to the efficiency of the quinone pool. This event indicates whether plastoquinones are active or not during the QA reduction process. When the $I$ band is found in negative values (on the graph), it suggests that the QA pool is functioning excellently, and an increase in the $J$ band is also observed, that is, this indicates that the interaction site is the reaction center (P680). The transient bands show exactly this effect (Figure 4A,B). Phase $I$ appears when a dynamic equilibrium is reached between the reduction of the plastoquinone pool by the electron flow from the PSII and its oxidation due to PSI activity [22].
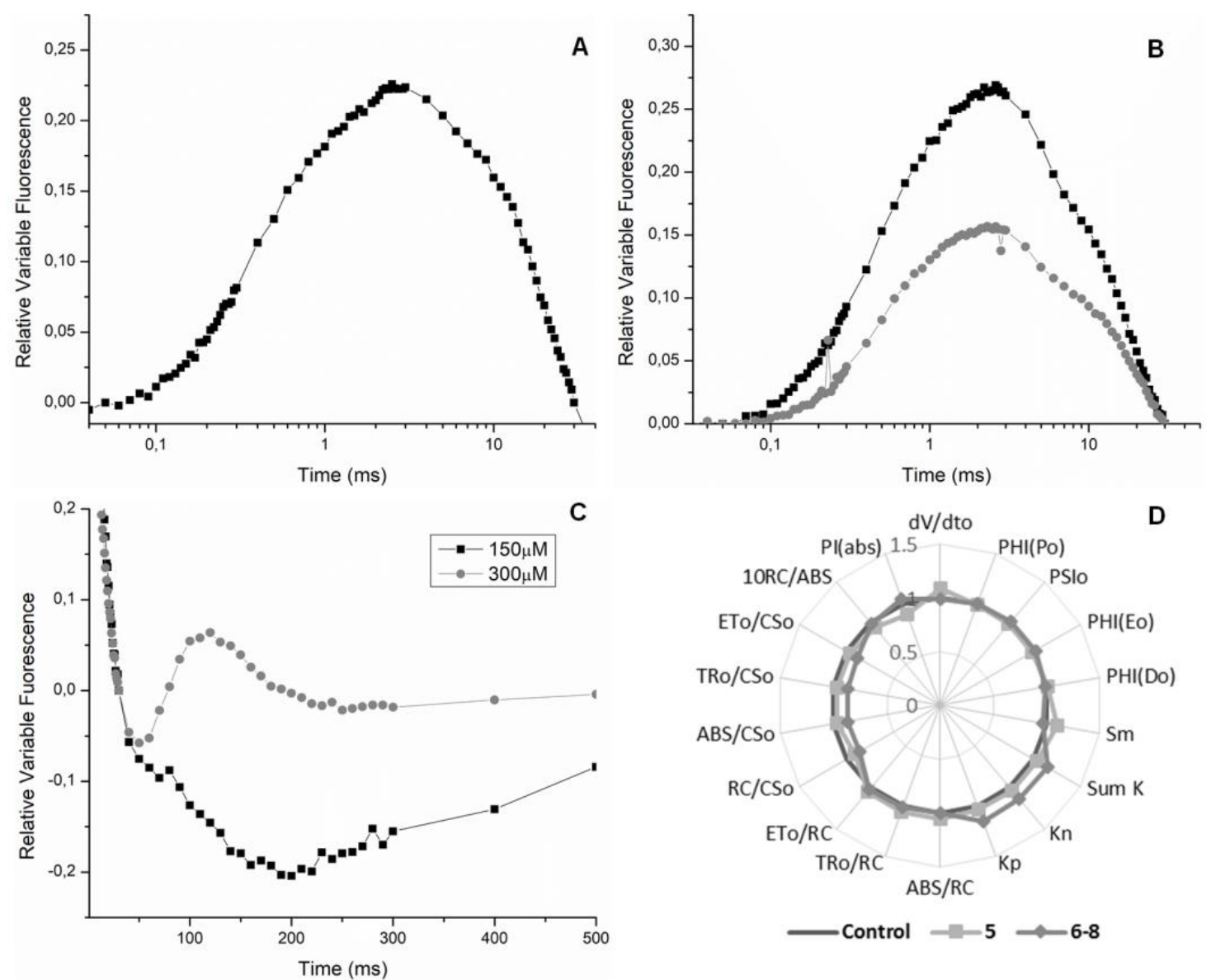

Figure 4. Panel (A) Appearance of the J-band in the presence of Compound 5 at $150 \mu \mathrm{M}$. Panel (B) Appearance of the J-band in the presence of Compounds 6-8 at 150 and $300 \mu \mathrm{M}$. Panel (C) Appearance of the I-band in the presence of 6-8 at 150 and $300 \mu \mathrm{M}$. Panel (D) Radar plot of Compounds $\mathbf{5}$ and 6-8 effects on Chl $a$ fluorescence parameters calculated from OJIP curve of sprayed Lolium perenne plants after $72 \mathrm{~h}$. 


\subsection{In Vivo Assays: Chl a Fluorescence Determination in Intact L. Perenne Leaves}

The in vivo Chl $a$ fluorescence experiment represents a powerful tool to evaluate the performance of the photosynthesis system in living plants without causing any damage to them [23]. To evaluate compound activity, solutions at 150 and $300 \mu \mathrm{M}$ were sprayed on the leaves of L. perenne plants. However, only Compound $\mathbf{5}$ and the mixture 6-8 were tested because they presented the best results on a semivivo assay. After 24,48 , and 72 h of treatment, $\mathrm{Chl} a$ fluorescence transients were measured and the OJIP parameters were calculated employing Biolyser HP software.

Data showed that $\mathbf{5}$ and $\mathbf{6 - 8}$ on plants after 24 and $48 \mathrm{~h}$ were insignificant, but a small variation on photosynthetic parameters was observed after $72 \mathrm{~h}$ at $150 \mu \mathrm{M}$ (Figure $4 \mathrm{D}$ ). In short, the in vivo results are less significant than the results observed on the semivivo assay. We justify this because there are many natural obstacles that the compounds have to transcend to reach their target (the chloroplast), for example, cell walls and membranes [23].

\subsection{Dry Biomass Determination}

Dry biomass results were obtained using L. perenne plants 15 days after compound application. Compound 5 and the mixture 6-8 were evaluated at 150 and $300 \mu \mathrm{M}$. The other compounds were not tested, as they did not present any activity in the previously assays. DCMU, a herbicide, was used as positive control (Table 4). Fortunately, the best results were observed for the lowest concentration, $150 \mu \mathrm{M}$. Treatments 5 and 6-8 decreased dry biomass by 20\% and 23\%, respectively, compared to negative control. These are significant results since they behaved like DCMU, which reduced $23 \%$ of the biomass of the target plant.

Table 4. Dry biomass assay for Compounds 5 and 6-8. Note: DCMU, 3-(3,4-dichlorophenyl)-1,1-dimethylurea.

\begin{tabular}{cccc}
\hline Treatment & $(\boldsymbol{\mu M})$ & Dry Biomass $(\mathbf{m g})$ & Percentage (\%) \\
\hline Control & 0 & $400.0 \pm 2.00$ & 100 \\
\hline DCMU & 10 & $307.0 \pm 1.54$ & 77 \\
\hline \multirow{2}{*}{5} & 150 & $320.0 \pm 1.60$ & 80 \\
& 300 & $327.0 \pm 1.64$ & 82 \\
\hline \multirow{2}{*}{$\mathbf{6 - 8}$} & 150 & $310.0 \pm 1.55$ & 77 \\
& 300 & $350.0 \pm 1.75$ & 87 \\
\hline
\end{tabular}

Based on in vitro, semivivo, and in vivo approaches, Compound 5 acts as a photosynthetic electron-transport inhibitor and as a plant-growth regulator. Mixture 6-8, on the other hand, acts as an electron-transport and energy-transfer inhibitor, as well as plant-growth regulator. Our results showed that almost all alkaloids behaved as photosynthesis inhibitors once some of them acted as Hill reaction inhibitors. Through fluorescence measurement, we could observe the presence of transient bands $J$ and $I$ (obtained from OJIP-test). These steps suggest that compounds isolated from $R$. graveolens inhibited electron flow on the acceptor side of PSII, exactly like DCMU does. Therefore, the aim of our work was to present that natural products still could be employed on programs to lead to new scaffold models for herbicides in the future, since natural products remains an interesting alternative to replace the commercial herbicides.

\section{Materials and Methods}

\subsection{Alkaloid Isolation from Ruta Graveolens}

The ethanolic extract (203.6 g) from Ruta graveolens leaves was solubilized in $\mathrm{CH}_{3} \mathrm{OH}: \mathrm{H}_{2} \mathrm{O}(1: 3, v: v)$ and extracted by liquid-liquid partition with hexane and dichloromethane to obtain the partitioned extract fractions. 
The dichloromethane fraction (14.6 g) from Ruta graveolens leaves was subjected to a chromatographic column using silica gel 60 (70-230 mesh), employing as a mobile phase increasing hexane, dichloromethane, acetone, and methanol concentrations to obtain 6 fractions (1-6). Fraction $5(0.746 \mathrm{~g})$ was subjected to a new chromatographic procedure using Sephadex LH-20 with isocratic elution formed by dichloromethane:methanol $(1: 1, v: v)$ to afford arborinine $(\mathbf{1}, 18.4 \mathrm{mg})$ and 1,4-dihydroxy-2,3-dimethoxy- $\mathrm{N}$-methylacridone $(2,16.5 \mathrm{mg})$ [24].

1-hydroxy-3-methoxy- $N$-methylacridone $(3,17.9 \mathrm{mg})$ was obtained from the dichloromethane:hexane fraction of Ruta graveolens leaves using silica gel (70-230 mesh) and solvents of increasing polarity (hexane, dichloromethane, acetone, and methanol), followed by a second chromatographic purification over Sephadex LH-20 with isocratic elution dichloromethane: methanol (1:1, v:v) [25].

From the methanol fraction of Ruta graveolens leaves, the $N$-methyl-4-methoxy-2-quinolone $(4,19.3 \mathrm{mg})$ and graveoline $(5,14.1 \mathrm{mg})$ compounds were purified using a chromatographic column with silica gel as support, and hexane, dichloromethane, acetone, and methanol as the mobile phase [26].

The ethanolic extract (7.0 g) from the Ruta graveolens roots was solubilized with methanol:water (1:3 v:v), and subjected to liquid-liquid extraction with hexane to provide the respective fraction (1.53 g). The hexanic fraction was subjected to purification using silica gel (70-230 mesh). The mobile phase was composed of increasing portions of hexane, dichloromethane, acetone, and methanol to obtain 8 fractions (I-VIII). Fraction II ( $0.105 \mathrm{~g})$ was subjected to new chromatographic purification by Sephadex LH-20 with isocratic elution dichloromethane:methanol $(3: 7, v: v)$ to obtain a homolog mixture of 6,7 , and 8 . The mixture was analyzed with GC-MS. The instrument was set to an initial temperature of $150{ }^{\circ} \mathrm{C}$, and maintained at that temperature for $1 \mathrm{~min}$. At the end of this period, the oven temperature was increased to $300{ }^{\circ} \mathrm{C}$, at the rate of $10^{\circ} \mathrm{C} / \mathrm{min}$, and maintained for $20 \mathrm{~min}$. The chromatogram presented 3 peaks at retention times $\left(t_{R}\right) 11.5 \mathrm{~min}(6, \mathrm{~m} / \mathrm{z} 313), 12.0 \mathrm{~min}(7, \mathrm{~m} / \mathrm{z} 327)$, and $13.0 \mathrm{~min}$ $(8, m / z 341)$. Based on the GC-MS experiment, a ratio of 8:1:1 (based on the peak areas) was estimated for 6,7 , and 8 [27].

Compound 1. ${ }^{1} \mathrm{H}-\mathrm{NMR}\left(200 \mathrm{MHz}, \mathrm{CDCl}_{3}\right) \delta: 3.81$ (s, 3H, N-Me), $3.92(\mathrm{~s}, 3 \mathrm{H}, 3-\mathrm{OMe}), 4.00(\mathrm{~s}, 3 \mathrm{H}$, 2-OMe), 6.23 (s, $1 \mathrm{H}, \mathrm{H}-4), 7.23$ (ddd, $J=8.0,6.8$ and $0.7 \mathrm{~Hz}, 1 \mathrm{H}, \mathrm{H}-7), 7,50$ (dl, $J=8.0 \mathrm{~Hz}, 1 \mathrm{H}, \mathrm{H}-5)$, $7.73(\mathrm{ddd}, J=8.0,6.8$ and $1.4 \mathrm{~Hz}, 1 \mathrm{H}, \mathrm{H}-6), 8.42(\mathrm{dd}, J=8.0$ and $1.4 \mathrm{~Hz}, 1 \mathrm{H}, \mathrm{H}-8), 14.75(\mathrm{~s}, 1 \mathrm{H}, \mathrm{OH})$. ${ }^{13} \mathrm{C}-\mathrm{NMR}\left(100 \mathrm{MHz}, \mathrm{CDCl}_{3}\right.$ ) $\delta: 34.1$ (N-Me), 56.0 (C3-OMe), 60.8 (C2-OMe), 86.8 (C-4), 105.8 (C-9a), 114.5 (C-5), 120.8 (C-8a), 121.5 (C-7), 126.2 (C-8), 130.2 (C-2), 134.6 (C-6), 140.5 (C-4a), 142.0 (C-5a), 156.2 (C-1), 159.3 (C-3), 180.8 (C-9).

Compound 2. ${ }^{1} \mathrm{H}-\mathrm{NMR}\left(200 \mathrm{MHz}, \mathrm{CDCl}_{3}\right) \delta: 3.96$ (s, 3H, N-Me), 3.99 (s, 3H, 2-OMe), 4.03 (s, 3H, 3-OMe), 7.32 (ddd, $J=8.0,7.5$ and $1.6 \mathrm{~Hz}, 1 \mathrm{H}, \mathrm{H}-7$ ), 7.48 (dl, $J=8.7 \mathrm{~Hz}, 1 \mathrm{H}, \mathrm{H}-5), 7.76$ (ddd, $J=8.7$, 7.5 and $1.6 \mathrm{~Hz}, 1 \mathrm{H}, \mathrm{H}-6), 8.36(\mathrm{dd}, J=8.7 \mathrm{and} 1,6 \mathrm{~Hz}, 1 \mathrm{H}, \mathrm{H}-8), 14.69(s, 1 \mathrm{H}, 1-\mathrm{OH}) .{ }^{13} \mathrm{C}-\mathrm{NMR}(50 \mathrm{MHz}$, $\mathrm{CDCl}_{3}$ ) 8: $44.0(\mathrm{~N}-\mathrm{Me}), 61.0$ (C2-OMe), 61.5 (C3-OMe), 109.4 (C-9a), 116.6 (C-5), 121.3 (C-8a), 122.1 (C-8), 126.2 (C-7), 134.6 (C-6), 134.7 (C-2), 140.0 (C-3), 146.1 (C-5a), 151.5 (C-4), 155.8 (C-1), 157.0 (C-4a), $182.3(\mathrm{C}-9)$.

Compound 3. ${ }^{1} \mathrm{H}-\mathrm{NMR}\left(200 \mathrm{MHz}, \mathrm{CDCl}_{3}\right) \delta: 3.77(\mathrm{~s}, 3 \mathrm{H}, \mathrm{N}-\mathrm{Me}), 3.90(\mathrm{~s}, 3 \mathrm{H}, \mathrm{OMe}), 6.30(\mathrm{~s}, 2 \mathrm{H}, \mathrm{H}-2$ and $\mathrm{H}-4), 7.30(\mathrm{ddd}, J=8.0,7.2$ and $1.6 \mathrm{~Hz}, 1 \mathrm{H}, \mathrm{H}-7), 7.40(\mathrm{dl}, J=8.0 \mathrm{~Hz}, 1 \mathrm{H}, \mathrm{H}-5), 7.73(\mathrm{ddd}, J=8.0,7.2$ and $1.6 \mathrm{~Hz}, 1 \mathrm{H}, \mathrm{H}-6), 8.44(\mathrm{dd}, J=8.0$ and $1.6 \mathrm{~Hz}, 1 \mathrm{H}, \mathrm{H}-8), 14.75(\mathrm{~s}, 1 \mathrm{H}, \mathrm{OH}),{ }^{13} \mathrm{C}-\mathrm{NMR}\left(50 \mathrm{MHz}, \mathrm{CDCl}_{3}\right)$ 8: 33.3 (N-Me), 55.6 (OMe), 90.1 (C-4), 94.1 (C-2), 105.0 (C-9a), 114.4 (C-5), 121.0 (C-8a), 121.4 (C-7), 126.7 (C-8), 134.1 (C-6), 142.0 (C-5a), 144.0 (C-4a), 166.0 (C-1), 166.1 (C-3), 180.0 (C-9). 
Compound 4. ${ }^{1} \mathrm{H}-\mathrm{NMR}\left(200 \mathrm{MHz}, \mathrm{CDCl}_{3}\right) \delta: 3.64$ (s, 3H, N-Me), 3.92 (s, 3H, OMe), 6.23 (s, $\left.1 \mathrm{H}, \mathrm{H}-3\right)$, $7.96(\mathrm{dd}, J=8.0$ and $1.5 \mathrm{~Hz}, 1 \mathrm{H}, \mathrm{H}-5), 7.21(\mathrm{ddd}, J=8.0,7.1$ and $1.5 \mathrm{~Hz}, 1 \mathrm{H}, \mathrm{H}-6), 7.34(\mathrm{dl}, J=8.0 \mathrm{~Hz}$, $1 \mathrm{H}, \mathrm{H}-8), 7.58$ (ddd, $J=8.0,7.1$ and $1.5 \mathrm{~Hz}, 1 \mathrm{H}, \mathrm{H}-7) .{ }^{13} \mathrm{C}-\mathrm{NMR}\left(50 \mathrm{MHz}, \mathrm{CDCl}_{3}\right) \delta: 28.8(\mathrm{~N}-\mathrm{Me})$, 55.3 (OMe), 96.1 (C-3), 113.8 (C-8), 116.2 (C-4a), 121.4 (C-6), 123.1 (C-5), 131.0 (C-7), 139.4 (C-8a), $162.4(\mathrm{C}-4), 163.6(\mathrm{C}-2)$.

Compound 5. ${ }^{1} \mathrm{H}-\mathrm{NMR}\left(400 \mathrm{MHz}, \mathrm{CDCl}_{3}\right) \delta: 3.59$ (s, 3H, N-Me), $5.99\left(\mathrm{~s}, 2 \mathrm{H}, \mathrm{H}-7^{\prime}\right), 6.26(\mathrm{~s} 1 \mathrm{H}, \mathrm{H}-3)$, $6.78\left(\mathrm{dd}, J=1.6\right.$ and $\left.0.4 \mathrm{~Hz}, 1 \mathrm{H}, \mathrm{H}-2^{\prime}\right), 6.81\left(\mathrm{dd}, J=8.0\right.$ and $\left.1.6 \mathrm{~Hz}, 1 \mathrm{H}, \mathrm{H}-6^{\prime}\right), 6.84(\mathrm{dd}, J=8.0$ and $0.4 \mathrm{~Hz}$, $\left.1 \mathrm{H}, \mathrm{H} 5^{\prime}\right), 7.34(\mathrm{ddd}, J=8.0,6.8$ and $1.6 \mathrm{~Hz}, 1 \mathrm{H}, \mathrm{H}-6), 7.49(\mathrm{dl}, J=8.4 \mathrm{~Hz}, 1 \mathrm{H}, \mathrm{H}-8), 7.64$ (ddd, $J=8.4$, 6.8 and $1.6 \mathrm{~Hz}, 1 \mathrm{H}, \mathrm{H}-7), 8.37(\mathrm{dd}, J=8.0$ and $1.6 \mathrm{~Hz}, 1 \mathrm{H}, \mathrm{H}-5)$.

Compounds 6-8. ${ }^{1} \mathrm{H}-\mathrm{NMR}\left(400 \mathrm{MHz}, \mathrm{CDCl}_{3}\right) \delta: 0.87\left(\mathrm{t}, J=8.0 \mathrm{~Hz}, 3 \mathrm{H}, \mathrm{CH}_{3}-9^{\prime}\right), 1.26-2.37\left(2 \mathrm{H}-2^{\prime}\right.$ to $2 \mathrm{H}-8^{\prime}$, overlapping with the signals of 7 and 8$), 3.05\left(\mathrm{qt}, J=8.0 \mathrm{~Hz}, 2 \mathrm{H}, \mathrm{H}-1^{\prime}\right), 4.12(\mathrm{~s}, 3 \mathrm{H}, N-\mathrm{Me})$, $6.70(\mathrm{~s}, 1 \mathrm{H}, \mathrm{H}-3), 7.54(\mathrm{tl}, J=8.0 \mathrm{~Hz}, 1 \mathrm{H}, \mathrm{H}-8), 7.77(\mathrm{tl}, J=8 \mathrm{~Hz}, 1 \mathrm{H}, \mathrm{H}-6), 8.19(\mathrm{tl}, J=8.0 \mathrm{~Hz}, 1 \mathrm{H}, \mathrm{H}-5)$, $8.19(\mathrm{tl}, J=8.0 \mathrm{~Hz}, 1 \mathrm{H}, \mathrm{H}-7)$.

\subsection{Chloroplast Isolation and Chlorophyll Quantitative Determination}

Intact chloroplasts were isolated from spinach leaves (Spinacea oleracea L.), as previously described $[12,22,25]$. Chlorophyll concentration was measured spectrophotometrically through a chloroplast suspension in a solution of $400 \mathrm{mM}$ sucrose, $5 \mathrm{mM} \mathrm{MgCl}, 10 \mathrm{mM} \mathrm{KCl}, 30 \mathrm{mM}$ tricine- $\mathrm{KOH}$, and $\mathrm{pH} 8.0$ [12].

\subsection{Measurement of Noncyclic Electron Transport Rate}

The light-induced noncyclic electron-transport activity from water to MV was determined polarographically employing a Clark-type electrode in the presence of $50 \mu \mathrm{M}$ of MV [19]. Basal electron transport was quantified by illuminating a solution of chloroplasts $(20 \mu \mathrm{g} \mathrm{Chl} / \mathrm{mL})$ in $3 \mathrm{~mL}$ of $100 \mathrm{mM}$ sorbitol, $10 \mathrm{mM} \mathrm{KCl}, 5 \mathrm{mM} \mathrm{MgCl}, 0.5 \mathrm{mM} \mathrm{KCN}, 15 \mathrm{mM}$ tricine- $\mathrm{KOH}$, and $50 \mu \mathrm{M} \mathrm{MV}$ at $\mathrm{pH} 8.0$ for $1 \mathrm{~min}$. The phosphorylating electron-transport rate was estimated for the basal electron transport from water to $\mathrm{MV}$, adding $1 \mathrm{mM}$ of $\mathrm{ADP}$ and $3 \mathrm{mM} \mathrm{KH}_{2} \mathrm{PO}_{4}$. In turn, uncoupled electron transport was evaluated in the same solution used for basal step, with $6 \mathrm{mM} \mathrm{NH}_{4} \mathrm{Cl}$ added as an uncoupler [12].

\subsection{Uncoupled PSI and PSII Electron-Flow Determination}

Electron-flow activities were monitored by an oxygen monitor yellow spring instrument model $5300 \mathrm{~A}$ using a Clark-type electrode. All reaction mixtures were illuminated with filtered light $(5 \mathrm{~cm}$ filter of $1 \% \mathrm{CuSO}_{4}$ solution) from a projector lamp (GAF 2660) at room temperature. For each reaction, a blank experiment was performed with chloroplasts in the reaction medium. Uncoupled PSII from $\mathrm{H}_{2} \mathrm{O}$ to DCPIP was measured through the reduction of DCPIP-supported $\mathrm{O}_{2}$ evolutions, monitored polarographically. The reaction medium for assaying PSII activity was composed by the same basal electron-transport medium, but in the presence of $1 \mu \mathrm{M}$ 2,5-dibromo-3-methyl-6isopropyl-1,4-p-benzoquinone (DBMIB), $100 \mu \mathrm{M} \mathrm{DCPIP}$, and $300 \mu \mathrm{M} \mathrm{K}_{3}\left[\mathrm{Fe}(\mathrm{CN})_{6}\right]$ and $6 \mathrm{mM} \mathrm{NH}_{4} \mathrm{Cl}$ [28].

To determine the uncoupled partial reaction of PSII from water to SiMo, solutions of $200 \mu \mathrm{M}$ of SiMo and $10 \mu \mathrm{M}$ of DCMU were added to the solution used for the PSII reactions $(3 \mathrm{~mL})$, then chloroplasts $(20 \mu \mathrm{g} \mathrm{Chl} / \mathrm{mL})$ were added and illuminated for $1 \mathrm{~min}$ [29].

Uncoupled PSI electron transport from the reduced DCPIP with sodium ascorbate to MV was determined in a similar form in a basal noncyclic electron-transport medium. However, the following reagents were added: $10 \mu \mathrm{M}$ DCMU, $100 \mu \mathrm{M}$ DCPIP, $50 \mu \mathrm{M}$ MV, $300 \mu \mathrm{M}$ sodium ascorbate, and $6 \mathrm{mM}$ $\mathrm{NH}_{4} \mathrm{Cl}$ [30]. All measurements were performed in triplicate and compared to negative control (solvent, dimethyl sulfoxide (DMSO)). 


\section{5. $H^{+}$-ATPase Activity Measurements}

Intact chloroplasts isolated from S. oleracea L. were resuspended in a solution of $0.35 \mathrm{M}$ sorbitol, $2 \mathrm{mM}$ EDTA, $1 \mathrm{mM} \mathrm{MgCl} 2 \cdot 6 \mathrm{H}_{2} \mathrm{O}, 1 \mathrm{mM} \mathrm{MnCl}$, and $50 \mathrm{mM}$ Hepes medium at $\mathrm{pH}$ 7.6. $\mathrm{H}^{+}$-ATPase activity was measured as reported [24]. $\mathrm{NH}_{4} \mathrm{Cl}$ and DMSO were employed as positive and negative controls, respectively. Pi was quantified using a UV spectrophotometer with measurements in $\lambda=660 \mathrm{~nm}$.

\subsection{Chlorophyll A Fluorescence Measurements in Spinach-Leaf Discs}

Ten $7 \mathrm{mM}$ leaf discs were placed in Petri dishes with $10 \mathrm{~mL}$ of a modified Krebs medium containing $115 \mathrm{mM} \mathrm{NaCl}, 5.9 \mathrm{mM} \mathrm{KCl}, 1.2 \mathrm{mM} \mathrm{MgCl}_{2}, 1.2 \mathrm{mM} \mathrm{KH}_{2} \mathrm{PO}_{4}, 1.2 \mathrm{mM} \mathrm{Na}_{2} \mathrm{SO}_{4}, 2.5 \mathrm{mM}$ $\mathrm{CaCl}_{2}$, and $25 \mathrm{mM} \mathrm{NaHCO}_{3}$ (pH 7.4). The Petri dishes were maintained in orbital stirring for $12 \mathrm{~h}$ at room temperature. All alkaloids, 1-8, were added to the system for a new period of stirring (12 h). The discs were dark-adapted for $30 \mathrm{~min}$ and chlorophyll $a$ fluorescence was measured at room temperature through a Hansatech Fluorescence Handy PEA (Plant Efficiency Analyzer, King's Lynn, UK) $[16,25]$.

\subsection{Plant Material for In Vivo Assays}

A suspension of Lolium perenne seeds prepared with $10 \%$ sodium hypochlorite solution was kept in an orbital shaker for $15 \mathrm{~min}$. Then, the sodium hypochlorite solution was removed and the seeds were washed 3 times with distilled water; 100 seeds were placed in $12 \mathrm{~cm}$ diameter pots containing a mixture of 50:25:25 $(w / w / w)$ soil/peat-moss/agrolite. All pots were watered daily and maintained in a greenhouse at $25-30{ }^{\circ} \mathrm{C}$ under normal day/night illumination (12/12 h). L. perenne plants were selected by uniformity after being 15 days old. The plants were separated in 3 groups: negative control (DMSO), positive control (50 $\mu \mathrm{M}$ of DCMU), and plants treated with each alkaloid at 150 and $300 \mu \mathrm{M}$ [12] by being manually sprayed.

\subsection{Chlorophyll a Fluorescence Determination in Intact L. Perenne Leaves and Dry Biomass Determination}

$\mathrm{Chl} a$ fluorescence was measured in leaves from the control plants and those treated with alkaloids 1-8 at 150 and $300 \mu \mathrm{M}$. After 24, 48, and $72 \mathrm{~h}$ of spraying, the leaves that adapted to the dark for $15 \mathrm{~min}$ were excited by light from an array of 3 light-emitting diodes delivering $3000 \mu \mathrm{mol} \mathrm{m}^{-2} \mathrm{~s}^{-1}$ of red light $(650 \mathrm{~nm})$. The $\mathrm{Chl} a$ fluorescence induction curves were measured at room temperature with a portable Hansatech Fluorescence Handy PEA apparatus. Photosynthetic parameters like as $\mathrm{PI}_{a b s}$, $\mathrm{dV} / \mathrm{dt}_{0}, \mathrm{Sm}, \mathrm{ABS} / \mathrm{RC}, \mathrm{TR}_{0} / \mathrm{RC}, \mathrm{ET}_{0} / \mathrm{RC}, \mathrm{TR}_{0} / \mathrm{ABS}, \mathrm{ET}_{0} / \mathrm{TR}_{0}, \mathrm{ET}_{0} / \mathrm{ABS}, \mathrm{PHI}\left(\mathrm{D}_{0}\right), \mathrm{ABS} / \mathrm{CS}_{0}, \mathrm{TR}_{0} / \mathrm{CS}_{0}$, $\mathrm{ET}_{0} / \mathrm{CS}_{0}, k \mathrm{p}, k \mathrm{n}$, and Sum $k$ were represented in a radar plot [12]. For the dry-biomass experiment, 15 days old $L$. perenne plants treated with alkaloids 1-8 at 150 and $300 \mu \mathrm{M}$ were dried in an oven at $65^{\circ} \mathrm{C}$ to reach a constant weight. Then, the dry biomass was measured using analytical balance [12].

Author Contributions: Conceptualization, T.A.M.V., B.L.-H. and O.M.S.; Methodology, B.S.B., O.M.S. and B.K.-D.; Software, L.C.C.V.; Validation, O.M.S. and B.K.-D.; Formal Analysis, B.S.B., O.M.S., T.A.M.V. and B.K.-D.; Investigation, O.M.S.; Resources, M.F.d.G.F.d.S. and B.L.-H.; Data Curation, O.M.S., T.A.M.V., L.C.C.V. and B.K.-D.; Writing-Original Draft Preparation, O.M.S.; Writing-Review and Editing, O.M.S., T.A.M.V. and L.C.C.V.; Visualization, O.M.S., T.A.M.V. and L.C.C.V.; Supervision, T.A.M.V., B.L.-H. and M.F.d.G.F.d.S.; Project Administration, B.L.-H. and M.F.d.G.F.d.S.; Funding Acquisition, B.L.-H. and M.F.d.G.F.d.S.

Funding: The authors gratefully acknowledge financial support from Grants DGAPA-UNAM, IN 205806; CNPq, and CAPES-Finance Code 001.

Acknowledgments: Olívia Moreira Sampaio thanks FAPESP (Fundação de Amparo a Pesquisa do Estado de São Paulo-Brazil) for the scholarship support.

Conflicts of Interest: The authors declare no conflict of interest. 


\section{Abbreviations}

$\begin{array}{ll}\text { ATP } & \begin{array}{l}\text { adenosine triphosphate } \\ \text { chlorophyll }\end{array} \\ \text { DBMIB } & \text { 2,5-dibromo-3-methyl-6-isopropyl-1,4- } p \text {-benzoquinone } \\ \text { DCMU } & \text { 3-(3,4-dichlorophenyl)-1,1-dimethylurea } \\ \text { DCPIP } & \text { 2,6-dichlorophenolindophenol } \\ \text { DMSO } & \text { dimethyl sulfoxide } \\ \text { MV } & \text { methylviologen } \\ \text { NADPH } & \text { dihydronicotinamide-adenine dinucleotide phosphate } \\ \text { Pi } & \text { inorganic phospate } \\ \text { PSI } & \text { photosystem I } \\ \text { PSII } & \text { photosystem II } \\ \text { RC } & \text { reaction center } \\ \text { SiMo } & \text { sodium silicomolybdate }\end{array}$

\section{References}

1. De Feo, V.; De Simone, F.; Senatore, F. Potential allelochemicals from the essential oil of Ruta graveolens. Phytochemistry 2002, 61, 573-578. [CrossRef]

2. Hale, A.L.; Meepagala, K.M.; Oliva, A.; Aliotta, G.; Duke, S.O. Phytotoxins from the leaves of Ruta graveolens. J. Agric. Food Chem. 2004, 52, 3345-3349. [CrossRef] [PubMed]

3. Kuzovkina, I.; Al'terman, I.; Schneider, B. Specific accumulation and revised structures of acridone alkaloid glucosides in the tips of transformed roots of Ruta graveolens. Phytochemistry 2004, 65, 1095-1100. [CrossRef] [PubMed]

4. Wansi, J.D.; Wandji, J.; Mbaze Meva'a, L.; Kamdem Waffo, A.F.; Ranjit, R.; Khan, S.N.; Asma, A.; Iqbal, C.M.; Lallemand, M.-C.; Tillequin, F.; Fomum-Tanee, Z. Alpha-glucosidase inhibitory and antioxidant acridone alkaloids from the stem bark of Oriciopsis glaberrima ENGL. (Rutaceae). Chem. Pharm. Bull. 2006, 54, 292-296. [CrossRef] [PubMed]

5. Michael, J.P. Quinoline, quinazoline and acridone alkaloids. Nat. Prod. Rep. 2007, 24, 223. [CrossRef] [PubMed]

6. Musiol, R.; Serda, M.; Hensel-Bielowka, S.; Polanski, J. Quinoline-Based Antifungals. Curr. Med. Chem. 2010, 17, 1960-1973. [CrossRef] [PubMed]

7. Lacroix, D.; Prado, S.; Kamoga, D.; Kasenene, J.; Bodo, B. Structure and in vitro antiparasitic activity of constituents of Citropsis articulata root bark. J. Nat. Prod. 2011, 74, 2286-2289. [CrossRef] [PubMed]

8. Torres-Romero, D.; King-Díaz, B.; Strasser, R.J.; Jiménez, I.A.; Lotina-Hennsen, B.; Bazz-Cchi, I.L. Friedelane triterpenes from celastrus vulcanicola as photosynthetic inhibitors. J. Agric. Food Chem. 2010, 58, 10847-10854. [CrossRef] [PubMed]

9. Menezes-De-Oliveira, D.; Aguilar, M.I.; King-Díaz, B.; Vieira-Filho, S.A.; Pains-Duarte, L.; De Fátima Silva, G.D.; Lotina-Hennsen, B. The triterpenes 3 $\beta$-Lup-20(29)-en-3-ol and 3 $\beta$-Lup-20(29)-en-3-yl acetate and the carbohydrate 1,2,3,4,5,6-hexa-O-acetyl-dulcitol as photosynthesis light reactions inhibitors. Molecules 2011, 16, 9939-9956. [CrossRef] [PubMed]

10. Sampaio, O.M.; de Castro Lima, M.M.; Veiga, T.A.M.; King-Díaz, B.; da Silva, M.F.d.G.F.; Lotina-Hennsen, B. Evaluation of antidesmone alkaloid as a photosynthesis inhibitor. Pestic. Biochem. Phys. 2016, 134, 55-62. [CrossRef] [PubMed]

11. Andreiadis, E.S.; Chavarot-Kerlidou, M.; Fontecave, M.; Artero, V. Artificial photosynthesis: From molecular catalysts for light-driven water splitting to photoelectrochemical cells. Photochem. Photobiol. 2011, 87, 946-964. [CrossRef] [PubMed]

12. McConnell, I.; Li, G.H.; Brudvig, G.W. Energy Conversion in Natural and Artificial Photosynthesis. Chem. Biol. 2010, 17, 434-447. [CrossRef] [PubMed]

13. Chen, S.; Zhou, F.; Yin, C.; Strasser, R.J.; Yang, C.; Qiang, S. Application of fast chlorophyll a fluorescence kinetics to probe action target of 3-acetyl-5-isopropyltetramic acid. Environ. Exp. Bot. 2011, 73, 31-41. [CrossRef]

14. Strasserf, R.J.; Srivastava, A. Govindjee polyphasic chlorophyll a fluorescence transient in plants and cyanobacteria. Photochem. Photobiol. 1995, 61, 32-42. [CrossRef] 
15. Hasan, C.; Ahmed, N.; Haque, R.; Haque, M.; Begum, S.; Sohrab, M.; Ahsan, M. Secondary metabolites from the stem of Ravenia spectabilis Lindl. Pharmacogn. Mag. 2013, 9, 76. [CrossRef] [PubMed]

16. Spatafora, C.; Tringali, C. Bioactive metabolites from the bark of Fagara macrophylla. Phytochem. Anal. 1997, 8, 139-142. [CrossRef]

17. Macías-Rubalcava, M.L.; García-Méndez, M.C.; King-Díaz, B.; Macías-Ruvalcaba, N.A. Effect of phytotoxic secondary metabolites and semisynthetic compounds from endophytic fungus Xylaria feejeensis strain SM3e-1b on spinach chloroplast photosynthesis. J. Photochem. Photobiol. B Biol. 2017, 166, 35-43. [CrossRef] [PubMed]

18. Hernández-Terrones, M.G.; Aguilar, M.I.; King-Diaz, B.; Lotina-Hennsen, B. Interference of methyl trachyloban-19-oate ester with CF0of spinach chloroplast H+-ATPase. Arch. Biochem. Biophys. 2003, 418, 93-97. [CrossRef]

19. Xiang, M.; Chen, S.; Wang, L.; Dong, Z.; Huang, J.; Zhang, Y.; Strasser, R.J. Effect of vulculic acid produced by Nimbya alternantherae on the photosynthetic apparatus of Alternanthera philoxeroides. Plant Physiol. Biochem. 2013, 65, 81-88. [CrossRef] [PubMed]

20. Paunov, M.; Koleva, L.; Vassilev, A.; Vangronsveld, J.; Goltsev, V. Effects of different metals on photosynthesis: Cadmium and zinc affect chlorophyll fluorescence in durum wheat. Int. J. Mol. Sci. 2018, 19. [CrossRef] [PubMed]

21. Marchi, G.; Marchi, E.C.S.; Wang, G.; Mcgiffen, M. Effect of age of a sorghum-sudangrass hybrid on its allelopathic action. Planta Daninha 2008, 26, 707-716. [CrossRef]

22. King-Díaz, B.; Dos Santos, F.J.L.; Rubinger, M.M.M.; Piló-Veloso, D.; Lotina-Hennsen, B. A diterpene $\gamma$-lactone derivative from Pterodon polygalaeflorus Benth. as a photosystem II inhibitor and uncoupler of photosynthesis. Z. Naturforsch. C 2006, 61, 227-233. [CrossRef] [PubMed]

23. Castelo-Branco, P.; Santos, F.J.L.; Rubinger, M.; Ferreira-Alves, D.; Piló-Veloso, D.; King, B.; Lotina-Hennsen, B. Inhibition and uncoupling of photosynthetic electron transport by diterpene lactone amide derivatives. Z. Naturforsch. C 2008, 63. [CrossRef]

24. Min, Y.D.; Kwon, H.C.; Yang, M.C.; Lee, K.H.; Choi, S.U.; Lee, K.R. Isolation of limonoids and alkaloids from Phellodendron amurense and their multidrug resistance (MDR) reversal activity. Arch. Pharm. Res. 2007, 30, 58-63. [CrossRef] [PubMed]

25. Seya, K.; Furukawa, K.-I.; Chiyoya, M.; Yu, Z.; Kikuchi, H.; Daitoku, K.; Motomura, S.; Murakami, M.; Oshima, Y.; Fukuda, I. 1-Methyl-2-undecyl-4(1H)-quinolone, a derivative of quinolone alkaloid evocarpine, attenuates high phosphate-induced calcification of human aortic valve interstitial cells by inhibiting phosphate cotransporter PiT-1. J. Pharmacol. Sci. 2016, 131, 51-57. [CrossRef] [PubMed]

26. Yruela, I.; Montoya, G.; Alonso, P.; Picorel, R. Identification of the Pheophytin-QA-Fe domain of the reducing side of the photosystem II as the Cu(II)-inhibitory binding site. J. Biol. Chem. 1991, 266, 22847-22850. [PubMed]

27. Giaquinta, R.T.; Dilley, R.A. A partial reaction in Photosystem II: Reduction of silicomolybdate prior to the site of dichlorophenyldimethylurea inhibition. Bioenergetics 1975, 387, 288-305. [CrossRef]

28. Garza-Ortiz, A.; King-Díaz, B.; Sosa-Torres, M.E.; Lotina-Hennsen, B. Interference of ruthenium red analogues at photosystem II of spinach thylakoids. J. Photochem. Photobiol. B Biol. 2004, 76, 85-94. [CrossRef] [PubMed]

29. Mills, J.D.; Mitchell, P.; Schürmann, P. Modulation of coupling factor ATPase activity in intact chloroplasts: The role of the thioredoxin system. FEBS Lett. 1980, 112, 173-177. [CrossRef]

30. Aguilar, M.I.; Romero, M.G.; Chávez, M.I.; King-Díaz, B.; Lotina-Hennsen, B. Biflavonoids isolated from Selaginella lepidophylla inhibit photosynthesis in spinach chloroplasts. J. Agric. Food Chem. 2008, 56, 6994-7000. [CrossRef] [PubMed]

Sample Availability: Samples of the compounds are not available from the authors. 